\title{
Simulation of biodiesel production using hydro-esterification process from wet microalgae
}

\author{
Yano Surya Pradana*, Ardian Fauzi, Sangga Hadi Pratama, and Hanifrahmawan Sudibyo \\ Chemical Engineering Department, Faculty of Engineering, Universitas Gadjah Mada, Jalan Grafika No. 2, Yogyakarta 55281, Indonesia
}

\begin{abstract}
Recently, algae have received a lot of attention as a new biomass source for the production of renewable energy, such as biodiesel. Conventionally, biodiesel is made through esterification or transesterification of oils where the process involves a catalyst and alcohol to be reacted in a reactor. However, this process is energy intensive for drying and extraction step. To overcome this situation, we studied simulation of a new route of hydro-esterification process which is combine hydrolysis and esterification processes for biodiesel production from wet microalgae. Firstly, wet microalgae treated by hydrolyzer to produce fatty acids (FAs), separated with separator, and then mixed with methanol and esterified at subcritical condition to produce fatty acid methyl esters (FAMEs) while $\mathrm{H}_{2} \mathrm{SO}_{4}$ conducted as the catalyst. Energy and material balance of conventional and hydrolysis-esterification process was evaluated by Aspen Plus. Simulation result indicated that conventional route is energy demanding process, requiring $4.40 \mathrm{MJ} / \mathrm{L}$ biodiesel produced. In contrast, the total energy consumption of hydrolysis-esterification method can be reduced significantly into $2.43 \mathrm{MJ} / \mathrm{L}$ biodiesel. Based on the energy consumption comparison, hydroesterification process is less costly than conventional process for biodiesel production.
\end{abstract}

\section{Introduction}

Today, population and industrial growth trigger the high energy requirement, especially for electricity and transportation as human life support [1]. From this case, renewable energy has an important role in the fulfillment of future energy demand in the world. It is intended to substitute fossil energy which is limited, unstable prices and causing greenhouse effect $[2,3]$. One of promising alternative energy to be developed is bio-based diesel fuel, called biodiesel.

Biodiesel can be produced from various oil feedstocks, which is divided into three generations. First generation of biodiesel feedstocks (G-1) is coming from edible vegetable oils, such as palm oil, soybean oil and sunflower oil. These feedstocks have high price and contradictive with food sector, although they generate high quality biodiesel. In order to improve economic value, biodiesel is initiated from second generation of biodiesel feedstocks (G-2), such as used cooking oil and palm fatty acid distillate [4]. These low-cost feedstocks produce medium-to-low quality biodiesel due to their impurities.

Recently, algae have received a lot of attention as a third generation (G-3) source for biodiesel production [5]. Indonesia, as tropical country, which gets sun a year around, has big potential for cultivating microalgae in large scale due to the need of sunlight for growing. Some of the main characteristics which set algae apart from other biomass are higher biomass production, higher oil or starch content, and do not require agricultural land [6].
Moreover, cultivation of microalgae can be utilized as $\mathrm{CO}_{2}$ removal and wastewater treatment medium in industry [7].

Generally, processes including in biodiesel production from microalgae are cultivation, harvesting, drying, oil extraction, oil transesterification/esterification [8]. Cost required for biodiesel production through these processes is high, which is less competitive than petroleumbased diesel. One of solution to overcome this problem is drying process elimination that requires high energy supply. In this case, oil extraction process is run with wet microalgae as fresh feed.

In oil extraction process, hydrolysis is proposed to convert wet microalgae into fatty acids in order to reduce energy supply compared to solvent extraction. By this process, water content in microalgae is very important to be used as hydrolysis medium. The next process is esterification to react fatty acids with alcohol producing biodiesel [9]. Both processes can be accelerated by using acid catalyst [10], which does not require catalyst separation between these two processes.

In this study, we studied simulation of a new route of hydro-esterification process which is combine hydrolysis and esterification processes for biodiesel production from wet microalgae. This route was expected to reduce energy supply which is effected on production cost. Wet microalgae treated by hydrolyzer to produce fatty acids and then

\footnotetext{
*Corresponding author: yanopradana@ugm.ac.id
} 
esterified with methanol at subcritical condition to produce fatty acid methyl esters while $\mathrm{H}_{2} \mathrm{SO}_{4}$ conducted as the catalyst. Material and energy balance of hydrolysisesterification process was evaluated by Aspen Plus and compared with conventional process.

\section{Methods}

\subsection{Materials}

Wet microalgae was represented by Chlorella sp., assumed as lipid $(2 \% \mathrm{w} / \mathrm{w})$, carbohydrate $(1.5 \% \mathrm{w} / \mathrm{w})$, protein $(5.5 \% \mathrm{w} / \mathrm{w})$ and water $(91 \% \mathrm{w} / \mathrm{w})$, algal oil was taken to be consist of fatty acids, represented as oleic acid, and biodiesel was represented as methyl oleate [10]. Supporting materials required to carry out hydroesterification process were methanol and sulfuric acid. Thermodynamic properties of major components used in this simulation were available on Table 1.

Table 1. Thermodynamic properties of components in biodiesel production from wet microalgae

\begin{tabular}{|l|c|c|c|}
\hline \multicolumn{1}{|c|}{ Properties } & $\begin{array}{c}\text { Oleic } \\
\text { acid }\end{array}$ & $\begin{array}{c}\text { Methyl } \\
\text { oleate }\end{array}$ & Methanol \\
\hline Chemical Formula & $\mathrm{C}_{18} \mathrm{H}_{34} \mathrm{O}_{2}$ & $\mathrm{C}_{19} \mathrm{H}_{36} \mathrm{O}_{2}$ & $\mathrm{CH}_{3} \mathrm{OH}$ \\
\hline $\begin{array}{l}\text { Molar mass } \\
(\mathrm{kg} / \mathrm{kmol})\end{array}$ & 282.46 & 296.55 & 32.04 \\
\hline Freezing point $\left({ }^{\circ} \mathrm{C}\right)$ & 13.0 & -20.0 & -97.6 \\
\hline Flash point $\left({ }^{\circ} \mathrm{C}\right)$ & - & 92.4 & 11.0 \\
\hline Density $\left(\mathrm{kg} / \mathrm{m}^{3}\right)$ & 895.0 & 873.0 & 792.0 \\
\hline Boiling point $\left({ }^{\circ} \mathrm{C}\right)$ & 360.0 & 351.4 & 64.8 \\
\hline Critical temp. $\left({ }^{\circ} \mathrm{C}\right)$ & 507.85 & 490.85 & 239.43 \\
\hline $\begin{array}{l}\mathrm{Critical} \mathrm{pressure} \\
(\mathrm{kPa})\end{array}$ & 1390.0 & 1280.0 & 8095.9 \\
\hline $\mathrm{H}^{\circ} \mathrm{f} 298, \mathrm{~L}(\mathrm{kcal} / \mathrm{mol})$ & -194.82 & -173.11 & -56.97 \\
\hline
\end{tabular}

\subsection{Procedures}

A new route of hydro-esterification process for biodiesel production from wet microalgae was simulated to observe the conversion profile and energy requirement in Aspen Plus. Simulation process mainly involved chemical components definition, thermodynamic model selection, capacity determination, and proper operating condition and unit selection. Non Random Two Liquid (NRTL) model was used to simulate the whole biodiesel production process [11].

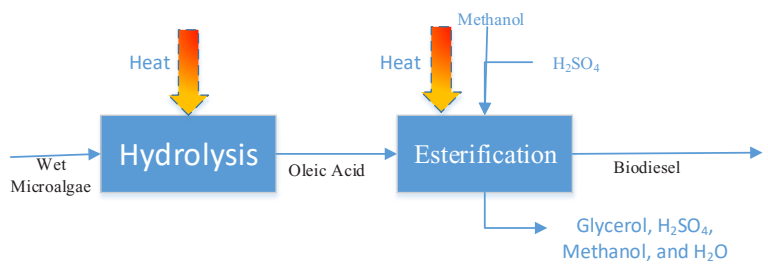

Fig. 1. Diagram of hydro-esterification process

Microalgae with total flow rate of $1000 \mathrm{kmol} / \mathrm{hr}$ was used as simulation basis. Hydrolyzer was operated at temperature of $260{ }^{\circ} \mathrm{C}$ and pressure of $5050 \mathrm{kPa}$, as known as subcritical condition. Esterification process was carried out in optimum temperature $\left(90-110{ }^{\circ} \mathrm{C}\right)$, pressurized condition, mass fraction of sulfuric acid of $1.0 \% \mathrm{w} / \mathrm{w}$ microalgae and methanol-oleic acid ratio of 9:1. The route of these processes was shown as block diagram in Fig. 1. Kinetics model of oleic acid esterification was developed by using observation data as shown in Table 2.

Table 2. Yield of biodiesel after 80 min of reaction [12]

\begin{tabular}{|c|c|c|c|}
\hline $\begin{array}{c}\text { Temperature } \\
{\left[{ }^{\circ} \mathrm{C}\right]}\end{array}$ & $\begin{array}{c}\text { Catalyst } \\
{[\% \mathrm{w} / \mathrm{w}]}\end{array}$ & $\begin{array}{c}\text { Alcohol to oleic } \\
\text { acid ratio }\end{array}$ & $\begin{array}{c}\text { Yield of } \\
\text { Biodiesel }[\%]\end{array}$ \\
\hline 90 & 1.0 & $9: 1$ & $87.0 \pm 0.3$ \\
110 & 1.0 & $9: 1$ & $88.2 \pm 0.3$ \\
\hline
\end{tabular}

Homogeneous model was considered in terms of a concentration in a batch reactor, which follows Eq. 1.

$$
-\frac{d C_{A}}{d t}=k_{A} \cdot C_{A} \cdot C_{M}-k_{A}^{-1} \cdot C_{F} \cdot C_{W}
$$

where $\mathrm{k}_{\mathrm{A}}$ and $\mathrm{k}_{\mathrm{A}}{ }^{-1}$ were the second order kinetic constant (forward and reverse reaction, respectively). Equation 1 can be changed to be reaction equilibrium as follows:

$$
-\frac{d C_{A}}{d t}=k_{A} \cdot\left(C_{A} \cdot C_{M}-\frac{C_{F} \cdot C_{W}}{K}\right)
$$

where, $\mathrm{C}_{\mathrm{A}}, \mathrm{C}_{\mathrm{M}}, \mathrm{C}_{\mathrm{F}}$ and $\mathrm{C}_{\mathrm{W}}$ were oleic acid, methanol, FAME, and water concentration $(\mathrm{mol} / \mathrm{L})$, respectively. Furthermore, $\mathrm{C}_{\mathrm{A}}, \mathrm{C}_{\mathrm{M}}, \mathrm{C}_{\mathrm{F}}$ and $\mathrm{C}_{\mathrm{W}}$ were expressed as a function of the FFAs conversion (X):

$$
\begin{gathered}
C_{A}=C_{A 0} \cdot(1-X) \\
C_{M}=C_{M 0}-C_{A 0} \cdot X \\
C_{F}=C_{W}=C_{A 0} \cdot X
\end{gathered}
$$

where $\mathrm{C}_{\mathrm{A} 0}$ and $\mathrm{C}_{\mathrm{M} 0}$ was initial concentration of oleic acid and methanol (mol/L), respectively.

Optimization of kinetic and equilibrium constant was carried out in MATLAB, following Arrhenius and Van't Hoff equation, as shown in Eq. 6 and 7:

$$
\begin{gathered}
k_{A}=A \exp \left(-\frac{E}{R T}\right) \\
\frac{d \ln K}{d T}=-\frac{\Delta H_{R}{ }^{o}}{R T^{2}}
\end{gathered}
$$

where A was collision factor; E was activation energy; $\mathrm{R}$ was ideal gas constant; $\mathrm{T}$ was temperature; $K$ was equilibrium constant; $\Delta H_{R}{ }^{\circ}$ was standard enthalpy change of reaction.

For further, optimized kinetic model was used to analyze the sensitivity biodiesel conversion over different operating condition and simulate mass and energy balance of hydro-esterification process by using Aspen Plus. To simplify the complexity of simulation, the following assumptions were taken. First, the mode of all heat exchangers were countercurrent. Second, the minimum temperature 
approached in all heat exchangers was set at $10{ }^{\circ} \mathrm{C}$. Third, the isentropic efficiency of compressors and pumps was assumed to be $80 \%$. The last one, the heat and pressure loss during the biodiesel production process were assumed to be negligible. The result of hydroesterification simulation was then compared to conventional biodiesel production, as shown in Fig. 2, reported by [8].

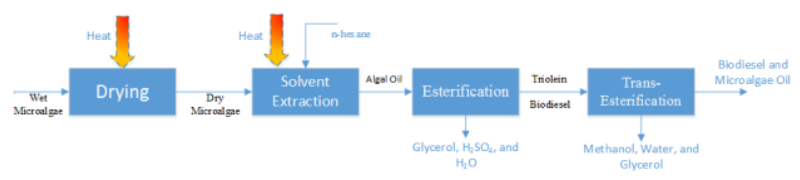

Fig. 2. Diagram of conventional biodiesel production from wet microalgae

\section{Results and Discussion}

Simulation of hydro-esterification in Aspen Plus was started by simulating hydrolysis process of wet microalgae. It utilized remaining water in harvested microalgae to produce fatty acids, represented as oleic acid, and glycerol. Simulation of this step applied NRTL thermodynamic model to calculate the mixture properties based on functional-groups that depict the components. Exception for triolein, the boiling point, density, pressure, critical temperature, and volume were determined by drawing the components inside the program.

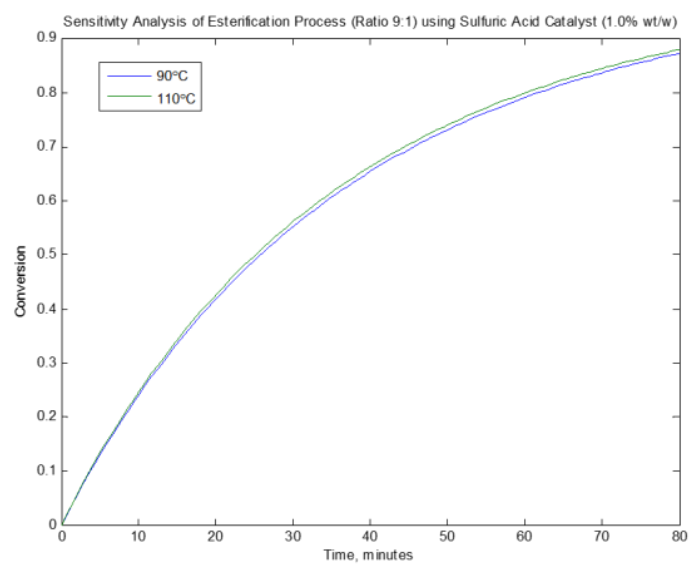

Fig. 3. Optimized kinetic model (2D) of oleic acid esterification (methanol-oleic acid ratio of 9:1 and sulfuric acid percentage of $1.0 \% \mathrm{w} / \mathrm{w})$

The oleic acid was then put into esterification reactor to convert oleic acid into methyl oleate. The kinetic model of this step was predicted by optimizing kinetic data in
Table 2, reported by [12] in Fig. 3 and Fig. 4 shows the trend of optimized kinetic model which was influenced by reaction temperature at methanololeic acid ratio of 9:1 and sulphuric acid percentage of $1 \% \mathrm{w} / \mathrm{w}$.

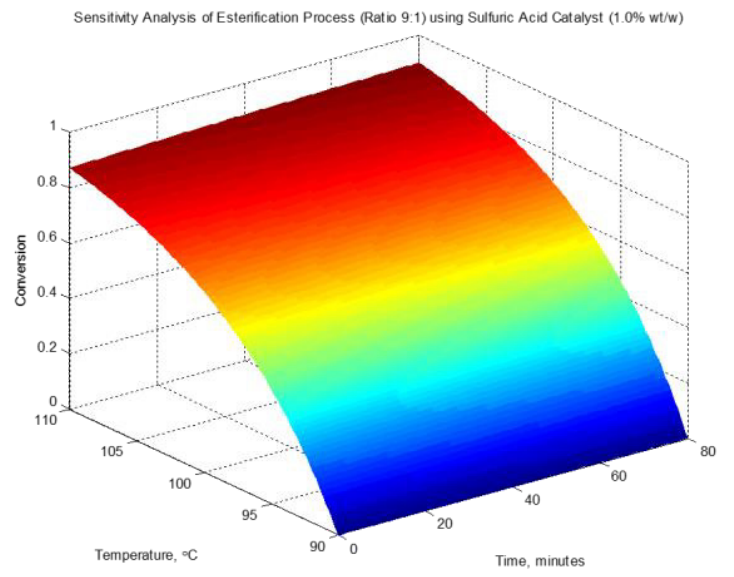

Fig. 4. Optimized kinetic model (3D) of oleic acid esterification (methanol-oleic acid ratio of 9:1 and sulfuric acid percentage of $1.0 \% \mathrm{w} / \mathrm{w}$ )

The change of reaction temperature $\left(90-110^{\circ} \mathrm{C}\right)$ did not increase biodiesel conversion significantly. It can be seen the slight differences of optimized kinetic constants in reaction temperature of 90 and $110^{\circ} \mathrm{C}$, as shown in Table 3. Thus, the simulation of oleic acid esterification used reversible kinetic model at reaction temperature of $90{ }^{\circ} \mathrm{C}$, methanololeic acid ratio of 9:1 and sulphuric acid percentage of $1 \% \mathrm{w} / \mathrm{w}$.

For those conditions, simulation of hydroesterification process resulted material and heat configuration, as shown in Table 4. In hydrolysis stage, the energy consumption is used to hydrolyze wet microalgae in order to avoid energy-intensive units, i.e. drying and extraction. In this simulation, the sensible heat of glycerol is recovered by heat exchanger to heat wet microalgae as heat integration effort. As a result, $56.31 \mathrm{kmol} / \mathrm{hr}$ of oleic acid could be produced with total energy consumption of hydrolysis process is $9.59 \mathrm{MW}$, equally $2.07 \mathrm{MJ} / \mathrm{L}$ biodiesel. In esterification stage, the energyintensive units are in heating and pumping process of methanol- $\mathrm{H}_{2} \mathrm{SO}_{4}$ mixture into $90{ }^{\circ} \mathrm{C}$ and 3 bar (1.05 MW). As a result, $48.92 \mathrm{kmol} /$ hour of methyl oleate could be produced with total energy consumption is $1.67 \mathrm{MW}$, equally $0.36 \mathrm{MJ} / \mathrm{L}$ biodiesel.

Table 3. Optimized kinetic and equilibrium constant

\begin{tabular}{|c|c|c|c|c|c|}
\hline Temperature $\left[{ }^{\circ} \mathbf{C}\right]$ & $\begin{array}{c}\text { Catalyst } \\
{[\% \mathbf{w} / \mathbf{w}]}\end{array}$ & $\begin{array}{c}\text { Methanol-Oleic } \\
\text { acid ratio }\end{array}$ & $\mathbf{k} \mathbf{k}[\mathbf{L} / \mathbf{m o l} / \mathbf{m i n}]$ & $\mathbf{K}$ & $\mathbf{E} / \mathbf{R}\left[\mathbf{1} /{ }^{\circ} \mathbf{C}\right]$ \\
\cline { 1 - 5 } 90 & 1.0 & $9: 1$ & 0.0031 & 0.0051 & \multirow{2}{*}{308.0269} \\
\cline { 1 - 4 } & 110 & $9: 1$ & 0.0032 & 0.0032 & \\
\hline
\end{tabular}


Table 4. Material and heat configuration in hydro-esterification simulation from wet microalgae

\begin{tabular}{|l|c|c|c|c|}
\hline \multirow{2}{*}{ Stream specification } & \multicolumn{2}{|c|}{ Hydrolysis } & \multicolumn{2}{c|}{ Esterification } \\
\cline { 2 - 5 } & \multirow{2}{*}{ Input } & Output & \multirow{2}{*}{ Input } & \multirow{2}{*}{ Output } \\
\hline Temperature, ${ }^{\circ} \mathrm{C}$ & 25 & 260 & 90 & 50 \\
\hline Pressure, bar & 101 & 5050 & 303 & 101 \\
\hline Total mass flow, kg/hr & 48252.98 & 48252.98 & 33120.13 & 33120.13 \\
\hline Total mole flow, kmol/hr & 1000.00 & 1096.58 & 573.01 & 573.01 \\
\hline Volume flow, $\mathrm{m}^{3} / \mathrm{hr}$ & 66.07 & 65.21 & 39.94 & 40.71 \\
\hline Component mole fraction, $(\%)$ & \multicolumn{3}{|l}{} \\
\hline Triolein & 0.0190 & 0.0010 & - & - \\
\hline Oleic acid & 0.0010 & 0.0510 & 0.0980 & 0.0130 \\
\hline Phenylalanine & 0.0550 & - & - & - \\
\hline Sucrose & 0.0150 & - & - & - \\
\hline Methanol & - & - & 0.8840 & 0.7990 \\
\hline $\mathrm{H}_{2}$ SO ${ }_{4}$ & - & - & 0.0170 & 0.0170 \\
\hline Water & 0.9100 & 0.7900 & - & 0.0850 \\
\hline Glycerol & - & 0.1580 & - & - \\
\hline Methyl Oleate & - & - & - & 0.0850 \\
\hline Enthalpy, GJ/hr & -83.4810 & -75.2270 & -41.3290 & -39.8880 \\
\hline
\end{tabular}

Fig. 5 shows compared energy consumed for biodiesel production using conventional and hydroesterification process. From this figure, conventional biodiesel production needs more energy to carry out all of processes. Total energy consumed by this process is $4.40 \mathrm{MJ} / \mathrm{L}$ biodiesel while hydro-esterification process is $2.43 \mathrm{MJ} / \mathrm{L}$ biodiesel. The highest contribution of energy consumption is drying process to remove water content [8], requiring $2.37 \mathrm{MJ} / \mathrm{L}$ biodiesel. In hydroesterification process, drying process is removed and hydrolysis is proposed to substitute solvent extraction, utilizing remaining water as agent.

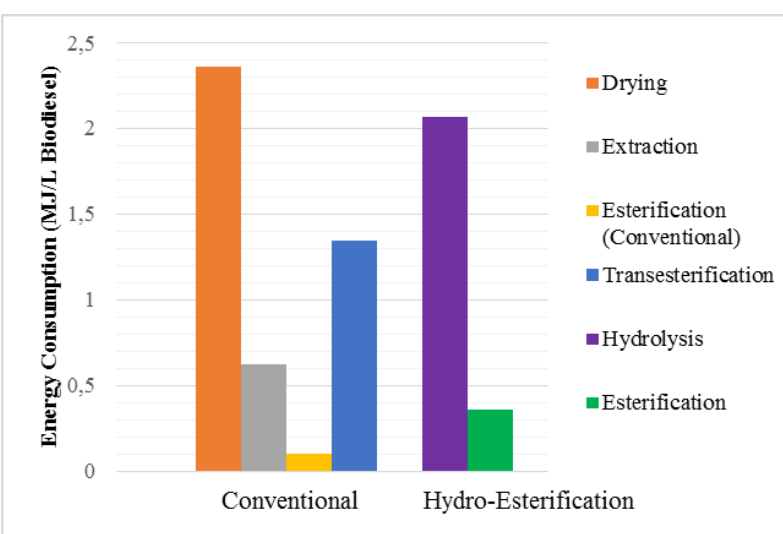

Fig. 5. Compared energy consumption of biodiesel production

\section{Conclusion}

In this study, the feasibility analysis of hydroesterification biodiesel production process from microalgae was investigated and compared with conventional route. Simulation results indicated that conventional route was energy demanding process, requiring $4.40 \mathrm{MJ} / \mathrm{L}$ for biodiesel production. In contrast, the total energy consumption of hydrolysisesterification method could be reduced significantly into $2.43 \mathrm{MJ} / \mathrm{L}$ biodiesel. Based on the energy consumption comparison, hydro-esterification process is less costly than conventional process for biodiesel production.

The authors are thankful to Universitas Gadjah Mada, Indonesia for financial support through Research Grant No. 365/DIT.LIT/2017.

\section{References}

1. M.K. Lam, K.T. Lee. Biotechnology Advances 30, 673-690 (2012)

2. M. Rahimi, B. Aghel, M.Alitabar, A. Sepahvand, H.R. Ghasempour, Energy Convers. Manag 79, 599-605 (2014) 
3. Y.S. Pradana, A. Prasetya, AIP Conference Proceedings 1823, 020069 (2017)

4. D.R. Sawitri, Sutijan, A. Budiman, ARPN Journal of Engineering and Applied Sciences, 11 (16), 9951-9957.

5. H. Sudibyo, Y.S. Pradana, T.T. Samudra, A. Budiman, Indarto, E.A. Suyono, , Energy Procedia 105, 270-276 (2017)

6. S.S. Oncel, Renewable and Sustainable Energy Reviews 26, 241-264 (2013)

7. Y.S. Pradana, Y. Kusumastuti, F.N. Rahma, N. Effendy, Chemical Engineering Transactions 56, 1549-1554 (2017)

8. C. Song. Q. Liu, N. Ji, S. Deng, J. Zhao, S. Li, Y. Kitamura, Bioresource Technology 214, 747-754 (2016)

9. R.D. Kusumaningtyas, S. Purwono, R. Rochmadi, A. Budiman, Int. J. Exergy 15 (4), 447-467 (2014)

10. G.D. Machado, T.L. de Souza, D.A.G. Aranda, F.L.P. Pessoa, M. Castier, V.F. Cabral, L. CardozoFilho, Chemical Engineering and Processing: Process Intensification 103, 37-45 (2016)

11. Y. Zhang, M.A. Dube, D.D. McLean, M. Kates, Bioresource Technology 89, 1-16 (2003)

12.I.L. Lucena, G.F. Silva, F.A.N. Fernandes, Industrial and Engineering Chemistry Research 47, 6885-6889 (2008) 